The following is an electronic version of a book chapter that was originally published as: Willis, R., Serenko, A., \& Turel, O. (2007). Contractual obligations between mobile service providers and users. In D. Taniar (Ed.), Encyclopedia of mobile computing and commerce (Vol. I) (pp. 143-148). Hershey, PA: Information Science Reference.

Copyright 2007, Idea Group Inc., www.igi-global.com. Posted by permission of the publisher.

More information about the Encyclopedia of mobile computing and commerce can be found at: http://www.igi-global.com/book/encyclopedia-mobile-computing-commerce/366 and more details about the chapter at: http://www.igi-global.com/chapter/contractual-obligations-between-mobileservice/17067. 


\section{Encyclopedia of Mobile Computing and Commerce}

David Taniar

Monash University, Australia

Volume I

A-Mobile Hunters 


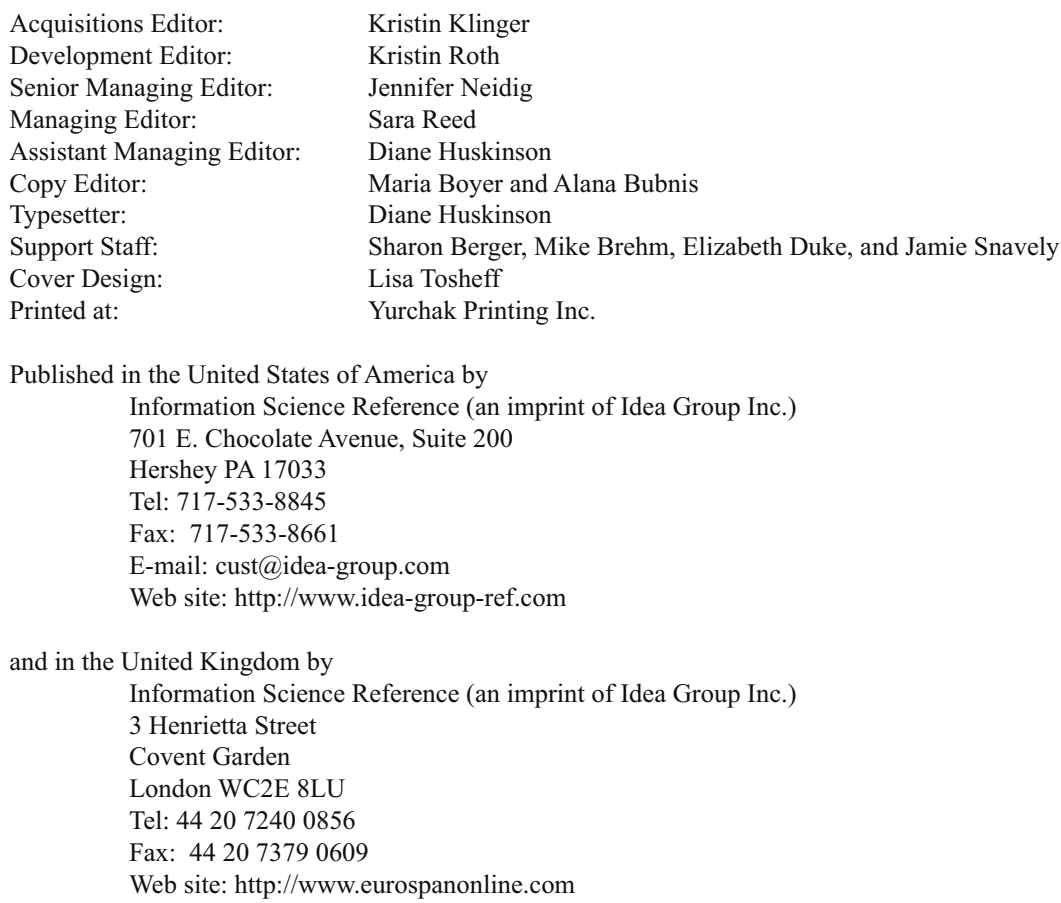

Copyright (C) 2007 by Idea Group Inc. All rights reserved. No part of this publication may be reproduced, stored or distributed in any form or by any means, electronic or mechanical, including photocopying, without written permission from the publisher.

Product or company names used in this set are for identification purposes only. Inclusion of the names of the products or companies does not indicate a claim of ownership by IGI of the trademark or registered trademark.

Library of Congress Cataloging-in-Publication Data

Encyclopedia of mobile computing and commerce / David Taniar, editor.

p. cm.

Summary: "Nowadays, mobile communication, mobile devices, and mobile computing are widely available. The availability of mobile communication networks has made a huge impact to various applications, including commerce. Consequently, there is a strong relationship between mobile computing and commerce. This book brings to readers articles covering a wide range of mobile technologies and their applications"--Provided by publisher.

Includes bibliographical references and index.

ISBN 978-1-59904-002-8 (hardcover) -- ISBN 978-1-59904-003-5 (ebook)

1. Mobile computing--Encyclopedias. 2. Mobile communication systems--Encyclopedias. 3. Mobile commerce--Encyclopedias. I. Taniar, David. QA76.59.E47 2007

$004.16503--d c 22$

\section{5}

British Cataloguing in Publication Data

A Cataloguing in Publication record for this book is available from the British Library.

All work contributed to this encyclopedia set is new, previously-unpublished material. The views expressed in this encyclopedia set are those of the authors, but not necessarily of the publisher. 


\title{
Contractual Obligations between Mobile Service Providers and Users
}

\author{
Robert Willis \\ Lakehead University, Canada \\ Alexander Serenko
Lakehead University, Canada \\ Ofir Turel \\ McMaster University, Canada
}

\section{INTRODUCTION}

The purpose of this chapter is to discuss the effect of contractual obligations between users and providers of mobile services on customer loyalty. One of the unique characteristics of mobile commerce that distinguishes it from most other goods and services is the employment of long-term contractual obligations that users have to accept to utilize the service. In terms of over-the-counter products, sold in one-time individual transactions in well-established markets, a strong body of knowledge exists that suggests that businesses may enhance loyalty through the improvement of quality and customer satisfaction levels. With respect to mobile commerce, however, this viewpoint may not necessarily hold true given the contractual nature of businesscustomer relationships.

In the case of mobile computing, it is suggested that loyalty consists of two independent yet correlated constructs that are influenced by different factors: repurchase likelihood and price tolerance. Repurchase likelihood is defined as a customer's positive attitude towards a particular service provider that increases the likelihood of purchasing additional services or repurchasing the same services in the future (e.g., after the contract expires). For example, when people decide to purchase a new mobile phone, they are free to choose any provider they want. In other words, repurchase likelihood is not affected by contractual obligations. In contrast, price tolerance corresponds to a probability of staying with a current provider when it increases or a competitor decreases service charges. In this situation, individuals have to break the existing contractual obligations. Currently, there is empirical evidence to suggest that the discussion above holds true in terms of mobile computing. However, there are few well-documented works that explore this argument in depth. This article attempts to fill that void.

This article will present implications for both scholarship and practice. In terms of academia, it is believed that researchers conducting empirical investigations on customer loyalty with mobile services should be aware of the two independent dimensions of the business-customer relationship and utilize appropriate research instruments to ensure the unidimensionality of each construct. With regards to practice, it is suggested that managers and marketers be aware of the differences between repurchase likelihood and price tolerance, understand their antecedents, and predict the consequences of manipulating each one. It is noted that overall loyalty is not the only multidimensional constuct in mobile commerce. Recently, it was emperically demonstrated that perceived value of short messaging services is a second-order construct that consists of several independent yet correlated dimensions (Turel et al., 2007).

Theoretical separation of the overall loyalty construct into two dimensions has been already empirically demonstrated in three independent mobile commerce investigations. First, Turel and Serenko (2006) applied the American customer satisfaction model (ACSM) to study mobile services in North America. By utilizing the original instrument developed by Fornell, Johnson, Anderson, Cha, and Bryant (1996), they discovered a low reliability of the overall satisfaction construct, and found that the correlation between two items representing price tolerance and one item reflecting repurchase likelihood was only $0.21(\mathrm{p}<0.01, \mathrm{~N}=204)$. Second, Turel et al. (2006) adapted the ACSM to study the consequences of customer satisfaction with mobile services in four countries (Canada, Finland, Israel, and Singapore), and reported that the correlation between price tolerance and repurchase likelihood was $0.20(\mathrm{p}<0.01, \mathrm{~N}=736)$. Third, Yol, Serenko, and Turel (2006) analyzed the ACSM with respect to mobile services in the U.S. and again found the same correlation to be 0.45 $(p<0.01, N=1,253)$. All these correlations fall into the smallto-medium range, and two of them are beyond the lowest cut-off value of 0.35 for item-to-total correlation (Nunnally $\&$ Bernstein, 1994). The statistical significance of these correlations is explained by large sample sizes. Therefore, it is impossible to design a single unidimensional construct in mobile commerce research consisting of both price tolerance 


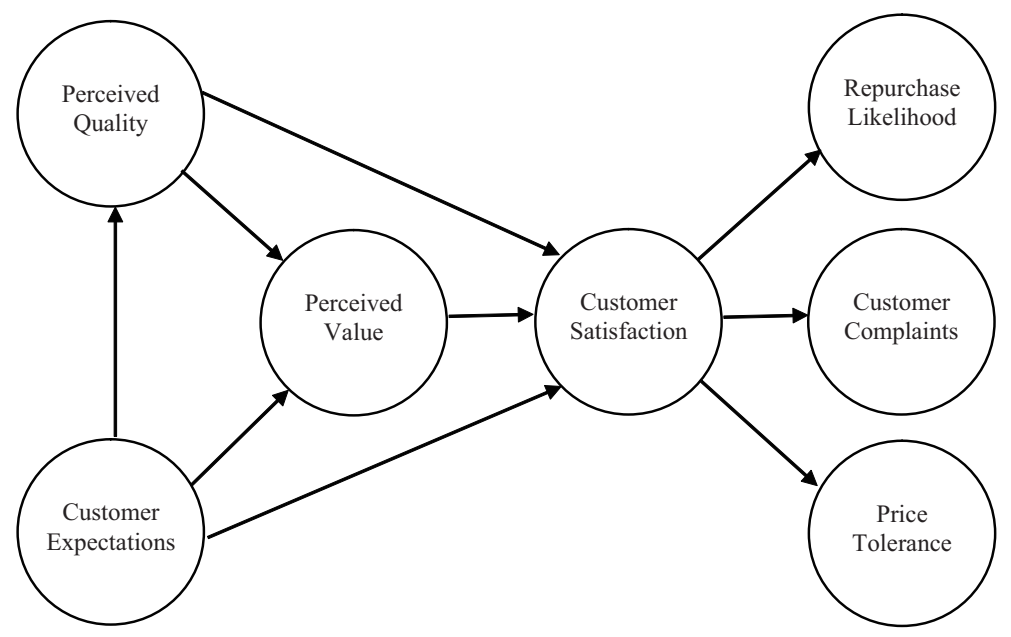

and repurchase likelihood. In all of these studies, most users had long-term contractual obligations with their respective mobile service provider that confirms the validity of the aforementioned conceptual discussion.

To better understand the customer loyalty concept in light of contractual obligations, this article briefly describes the American customer satisfaction model (ACSM), and then discusses the concepts of price tolerance and repurchase likelihood. Finally, it presents a summary which outlines implications for research and practice.

\section{THE AMERICAN CUSTOMER SATISFACTION MODEL}

The mobile telephony market continues to be one of the fastest growing service sector markets, creating a fiercely competitive industry environment (Kim \& Yoon, 2005). As has happened in other, subscription-based mobile service industries, the nature of this competition has changed from the acquisition of new customers to the retention of existing customers and the luring away of competitors' customers. This last strategy is known in the industry as outbound churn or, more simply, as churn. Given the increasing penetration of mobile computing devices and the maturation of the market, avoiding churn and maximizing customer loyalty has become a primary concern for wireless providers. The first step in minimizing churn in a company's customer base is to understand its root causes.

The determinants of churn may be estimated by the adapted American Customer Satisfaction Model (see Figure 1). The original model suggests that satisfaction affects overall customer loyalty, where loyalty is a unidimensional construct that consists of price tolerance (i.e., the probability of staying with the current provider if it increases prices or if a competitor decreases prices) and repurchase likelihood (i.e., the probability of purchasing the same service again). At the same time, several recent works suggest that these loyalty dimensions are distinct yet correlated because of the contractual nature of the customer-service provider relationship.

Customer loyalty is one of the major constructs in marketing, and a large part of a marketing manager's effort is aimed at creating and maintaining loyalty among an organization's customer base. The significance of loyalty comes from the positive impact it has on the operations of the company in terms of customer retention, repurchase, long-term customer relationships, and company profits (Caruana, 2004). In other words, loyalty is a primary factor in reducing churn.

The notion of switching costs affecting loyalty has been recognized and researched by several professional and academic disciplines, including marketing, economics, and strategy. "Switching costs are generally defined as costs that deter customers from switching to a competitor's product or service" (Caruana, 2004, p. 256). For managers and researchers, it is important to understand the concepts of switching costs and customer loyalty, and to clearly identify both their dimensions and their interaction.

\section{PRICE TOLERANCE}

Switching costs are generally defined as one-time costs facing the consumer/buyer of switching from one supplier to another (Porter, 1980; Burnham, Frels, \& Mahajan, 2003). Several researchers have identified various attributes or types of switching costs (e.g., Thibault \& Kelly, 1959; Klemperer, 1987; Guiltnan, 1989; Burnham et al., 2003; Hu \& Hwang, 
2006); however, for the purposes of this article, switching costs are broadly categorized as three types: transaction, learning, and contractual. Transaction costs are costs incurred when a consumer begins a relationship with a provider and includes the costs associated with ending that relationship or terminating an existing relationship. Learning costs are associated with the effort required by the consumer to achieve the same level of knowledge and comfort acquired using a particular supplier's product, but which may not be transferable to similar/same products of other suppliers. Additionally, the notion of learning costs incorporates the implicit switching costs associated with decision biases, risk aversion, and market knowledge/familiarity. Learning what one's options are, what the relative competitive position of all suppliers are, and other such knowledge involves learning costs that will be differentially valued by individuals. In the case of mobile services, the switching costs are created by a service provider that requires customers to sign a long-term contract. If a customer wants to switch to another provider, he or she will have to pay a penalty to the current provider. As such, contractual costs are those costs that are directly provider induced in order to penalize churn and which are intended to prevent poaching of customers by other suppliers. With respect to the American customer satisfaction model, switching costs directly affect price tolerance. The ACSM survey instrument presents two questions: (1) by how much their current provider should increase its current prices in order for them to switch to a competitor, and (2) by how much a competitor should reduce its prices in order for them to switch. Peoples' answers to these questionnaire items are greatly affected by the direct switching costs they incur, such as a penalty.

Consistent with this proposition, Weiss and Anderson (1992) found that switching costs are a major consideration when consumers are making a churn decision, and that these costs (barriers) tend to reduce customers' churn behavior. These findings were further supported by research done by Jones, Mothersbaugh, and Beatty (2000). Burnham et al. (2003) suggested that switching costs are negatively correlated with a customer's intention to churn: the higher the costs, the lower the intention to switch. As Hu and Hwang (2006) point out, "the industry remains in a state of dynamic competition" (p. 75) and providers continue implementing flexible offerings that are aimed at reducing consumers' churn behavior. Shapiro and Varian (1999) found that perceived switching costs - which incorporate all of the explicit costs as well as the implicit costs discussed above — act as barriers to churn behavior. They suggest consumers will weigh the benefits of switching against the actual and psychological costs when considering churning.

Overall, the discussion above demonstrates that the concept of switching barriers has its own unique dimensions. In terms of the American customer satisfaction model applied in the context of mobile services, it is believed that two items pertaining to the customer switching behavior (conceptualized as price tolerance in the model) reflect a unique latent variable entitled price tolerance.

\section{REPURCHASE LIKELIHOOD}

The notion of overall customer loyalty has changed in both breadth and depth over the years in which it has been studied by academics and practitioners alike. The breadth of its definition is demonstrated by the multiplicity of areas that are examined, such as brand, product, vendor, or service loyalty. Initial research was primarily focused on brand loyalty, and mostly examined the behavioral aspects of the construct. In this view, Newman and Werbel (1973) defined customer loyalty as the repurchase of a brand that only considered that brand and which involved no brand-related information seeking.

Day (1969) was one of the first researchers to highlight the role of a positive attitude in the construct of loyalty. Following this line of reasoning, which incorporated both the behavioral and attitudinal conceptions of loyalty, operationalization of the construct of customer loyalty involved combining the aspects of purchasing a particular brand together with an affective attitudinal measure, whether that measure used a single scale or multi-scale items. With regards to the American customer satisfaction model, the discussion above relates to the unique dimension of loyalty as repurchase likelihood, or the probability of buying new services from the current provider when these purchases are not affected by prior contractual obligations, for example, when a contract has expired.

\section{PRICE TOLERANCE AND REPURCHASE LIKELIHOOD}

The literature - and intuition — suggests that higher switching costs are positively related to price tolerance - that is, that higher switching costs compel customers to remain loyal. Fornell et al. (1996) were among the first to include switching costs by adding them to the construct of customer satisfaction in the reflection of customer loyalty. In the ACSM, all items (i.e., two pertaining to price tolerance and one relating to repurchase likelihood) were believed to reflect overall loyalty. A number of subsequent studies demonstrated the unidimensionality of this construct. However, in the context of mobile services when high switching costs exist, unidimensionality does not apply. As such, it is suggested that, based on the theoretical rationale as well as empirical studies cited earlier, loyalty should be analyzed along two distinct dimensions: price tolerance and repurchase likelihood.

In terms of prior empirical research, Jones and Sasser (1995) included switching costs as one factor or competi- 
tiveness: since high switching costs discourage churning, they reduce the incentive for firms to compete. Bateson and Hoffman (1999) similarly suggest that customer satisfaction and switching costs are the primary influencers of loyalty. More recent studies have shown that switching costs have a direct and strong influence on the re-purchase decision (customer loyalty) in all markets, for example France (Lee, Lee, \& Feick, 2001), Korea (Kim \& Yoon, 2005), Australia (Caruana, 2004), Taiwan (Hu \& Hwang, 2006), and Turkey (Aydin, Özer, \& Arasil, 2005).

Jones et al.'s (2000) study examined the role of switching costs (barriers) in customer retention for services. They found that although core-service satisfaction was a primary issue in retention, switching factors in the form of interpersonal relationships, direct and indirect costs, and the perceived benefits of potential alternatives were also important. As such, these factors represented different unique dimensions of the overall loyalty concept. This supports the notion, outlined above, that loyalty of mobile service users must be considered as multidimensional and not simply as direct, contractual costs.

\section{IMPACTS FOR MANAGERS AND RESEARCHERS}

The findings of the many studies in the area show support for the intuitive link between higher switching costs and greater levels of customer loyalty (or at least, retention). More importantly, they also provide a greater understanding of the interaction between switching costs and loyalty, and refine the model that has, to date, served as a guide to management of mobile phone companies.

Management of mobile phone companies must understand the complexity and multidimensionality of the concepts of switching costs that directly influence price tolerance and repurchase likelihood that is not affected by contractual obligations. They must also understand that switching costs affect customer loyalty not solely through the contractual cost component of switching costs, but also through the learning and transaction cost components. A customer's, or potential customer's, belief that he or she will end up with a 'bad deal' financially in switching to a new provider — and that assessment will include all of the implicit as well as explicit costs - is the most important issue in the churn decision. This highlights the point that managing customer relationships, so that they remain positive, acts to keep the customer attached, whether this is a result of satisfaction outweighing perceived benefits or simply of customer inertia (Burnham et al, 2003; Caruana, 2004). It also highlights the need for poaching strategies to emphasize not only the financial benefits, but the relational benefits as well (Hu \& Hwang, 2006). It should be noted that existing studies point out that one of the primary issues affecting the learning cost component has been the lack of time to undertake a complete comparison of the many offerings in the market. Additionally, providers have tended in the past to couch their offerings in terms that vary widely from their competitors', thus introducing a level of uncertainty and confusion in the minds of the analyzing consumer $(\mathrm{Hu}$ \& Hwang, 2006). These factors are becoming less and less viable as consumers turn to the Internet for their purchasing information and guidance, and as consumers demand-and get - a certain level of standardization in the offerings of providers in the market, whether that standardization comes from the providers themselves or from organizations that perform such analyses and offer them to the consuming (Internet- or magazine-based) consumer. Additionally, the increasing homogeneity of pricing strategies and service packages will lead to a lessening of the impact of explicit (transaction and contractual) switching costs on the churn decision (Hu \& Hwang, 2006). Thus, management needs to concentrate on customer relationships. Swartz(2000) quotes two senior executives in the industry:

If service is poor, then customers will pay any cancellationfees to get rid of the service and choose another provider....

You have to look at your reasons for churn...Y You can't use a contract to make up for poor service. If your service is poor, you can lock them in for a year...but they're gone the minute month 13 rolls around.

More research needs to be done on the notion of overall loyalty as a multidimensional construct. Are there positive barriers, such as interpersonal relationships, as well as negative? What relative influence on customer satisfaction do core and non-core services have? How sensitive are costs as barriers? Research into whether or not there are services that are perceived as having low barriers as opposed to services that are perceived as having high barriers within the market offerings would help refine our understanding of the role of various costs.

\section{REFERENCES}

Aydin, S., Özer, G., \& Arasil, Ö. (2005). Customer loyalty and the effect of switching costs as a modifier variable: A case in the Turkish mobile phone market. Marketing Intelligence and Planning, 23(1), 89-103.

Bateson, J. E. G., \& Hoffman, K. D. (1999). Managing services marketing, text and readings ( $4^{\text {th }} \mathrm{ed}$.). Fort Worth, TX: Dryden Press.

Burnham, T. A., Frels, J. K., \& Mahajan, V. (2003). Consumer switching costs: A typology, antecedents and con- 
sequences. Journal of the Academy of Marketing Science, 31(2), 109-126.

Caruana, A. (2004). The impact of switching costs on customer loyalty: A study among corporate customers of mobile telephony. Journal of Targeting, Measurement and Analysis for Marketing, 12(3), 256-268.

Day, G. S. (1969). A two dimensional concept of brand loyalty. Journal of Advertising Research, 9(3), 29-36.

Fornell, C. (1992). A national consumer satisfaction barometer: The Swedish experience. Journal of Marketing, $56(1), 6-21$.

Fornell, C., Johnson, M. D., Anderson, E. W., Cha, J., \& Bryant, B. E. (1996). The American Customer Satisfaction Index: Nature, purpose, and findings. Journal of Marketing, 60(4), 7-18.

Guiltnan, J.P. (1989). A classification of switching costs with implications for relationship marketing. In T. L. Childers \& R. P. Bagozzi (Eds.), Proceedings of the Winter Educators' Conference: Marketing Theory and Practice (pp. 216-220), Chicago.

Hu, A.W.-L., \& Hwang, I.-S. (2006). Measuring the effects of consumer switching costs on switching intention in Taiwan mobile telecommunications services. Journal of American Academy of Business, 9(1), 75-85.

Jones, M. A., Mothersbaugh, D. L., \& Beatty, S. E. (2000). Switching barriers and repurchase intentions in services. Journal of Retailing, 76(2), 259-274.

Jones, T. O, \& Sasser, W. E. (1995). Why satisfied customers defect. Harvard Business Review, 73(1), 88-99.

Kim, H.-S., \& Yoon, C.-H. (2004). Determinants of subscriber churn and customer loyalty in the Korean mobile telephony market. Telecommunications Policy, 28, 751-756.

Klemperer,P. (1987). Markets with consumer switching costs. The Quarterly Journal of Economics, 102, 375-394.

Lee, J., Lee, J., \& Feick, L. (2001). The impact of switching costs on customer satisfaction-loyalty link: Mobile phone service in France. Journal of Services Marketing, 15(1), $35-48$.

Newman, J. W., \& Werbel, R.A. (1973). Multivariate analysis of brand loyalty for major household appliances. Journal of Marketing Research, 10(4), 404-409.

Nunnally, J.C., \& Bernstein, I.H.(1994). Psychometric theory ( $3^{\text {rd }}$ ed.). New York: McGraw-Hill.

Oliver, R. L. (1996). Satisfaction: A behavioral perspective on the consumer. New York: McGraw-Hill.
Porter, M. E. (2003). Competitive strategy: Techniques for analyzing industries and competitors. New York: MacMillan.

Serenko, A., Turel, O., \& Yol, S. (2006). Moderating roles of user demographics in the American customer satisfaction model within the context of mobile services. Journal of Information Technology Management, 17(4): in-press.

Swartz, N. (2000). Reconsidering contracts. Wireless Review, $17(4), 48-52$

Thibault, J. W., \& Kelley, H. H. (1959). The social psychology of groups. New York: John Wiley \& Sons.

Turel, O., \& Serenko, A. (2006). Satisfaction with mobile services in Canada: An empirical investigation. Telecommunications Policy, 30(5-6), 314-331.

Turel, O., Serenko, A., \& Bontis, N. (2007). User acceptance of wireless short messaging services: Deconstructing perceived value. Information \& Management, 44(1), 63-73.

Turel, O., Serenko, A., Detlor, B., Collan, M., Nam, I., \& Puhakainen, J. (2006). Investigating the determinants of satisfaction and usage of mobile IT services in four countries. Journal of Global Information Technology Management, 9(4), 6-27.

Weiss, A.M., \& Anderson, E. (1992). Converting from independent to employee sales forces: The role of perceived switching costs. Journal of Marketing Research, 29(1), 101-115.

\section{KEY TERMS}

American Customer Satisfaction Model: The original model suggests that satisfaction affects the overall customer loyalty, where loyalty is a unidimensional construct that consists of price tolerance (i.e., the probability of staying with the current provider if it increases prices or if a competitor decreases prices) and repurchase likelihood (i.e., the probability of purchasing the same service again). If the customer's expectations of product quality, service quality, and price are exceeded, a firm will achieve high levels of customer satisfaction and will create customer delight. If the customer's expectations are not met, customer dissatisfaction will result. And the lower the satisfaction level, the more likely the customer is to stop buying from the firm.

Churn: This refers to the notion that a company will, over any given period of time, lose existing customers and gain new customers. Churn is, currently, mostly created by the luring away of competitors' customers.

Customer Loyalty: The notion that a customer will continue to use a particular brand or product; the behavior 
customers exhibit when they make frequent repeat purchases of a brand or product.

Price Tolerance: The extent to which price is an important criterion in the customer's decision-making process; thus a price-sensitive customer is likely to notice a price rise and switch to a cheaper brand or supplier.

Repurchase Likelihood: The probability of buying new services from the current provider when these purchases are not affected by prior contractual obligations, for example, when a contract has expired.
Switching Cost: One-time cost facing the consumer/ buyer of switching from one supplier to another. Switching costs are composed of transaction costs (costs incurred when a consumer begins a relationship with a provider, and includes the costs associated with ending that relationship or terminating an existing relationship), learning costs (costs associated with the effort required by the consumer to achieve the same level of knowledge and comfort acquired using a particular supplier's product, but which may not be transferable to the same/similar products of other suppliers), and contractual costs (costs that are directly provider induced in order to penalize churn and which are intended to prevent poaching of customers by other suppliers). 